This is a self-archived version of an original article. This version may differ from the original in pagination and typographic details.

Author(s): Jakonen, Mikko

Title: Demokratia tekee meistä älykkäitä

Year: 2018

Version: Published version

Copyright: (c) 2018 Mikko Jakonen

Rights: In Copyright

Rights url: http://rightsstatements.org/page/lnC/1.0/?language=en

Please cite the original version:

Jakonen, M. (2018). Demokratia tekee meistä älykkäitä. Tiede ja edistys, 43(1), 85-88.

https://doi.org/10.51809/te.105281 


\section{DEMOKRATIA TEKEE MEISTÄ ÄLYKKÄITÄ}

Kai Alhanen \& Tuukka Perhoniemi:

Demokraattinen perintömme. Vastapaino,

Tampere 2017.

Demokratia on kriisissä. Tätä näkökulmaa toitotetaan nykyisin monista suista. Kriisistä kertovat esimerkiksi populistit, jotka kokevat demokratian valuneen "vanhojen puolueiden", "herrojen" ja "eliitin" käsiin. Heidän mukaansa tarvitaan radikaaleja muutoksia, jotta demokratia voitaisiin palauttaa takaisin kansalle, sillä "kyllä kansa tietää” mikä olisi oikein, herrat eivät vain kuuntele.

Eivätkä he kuuntelekaan, sillä jopa liberaalina pidetty pitkän linjan poliitikko Pekka Haavisto presidentinvaalikampanjassaan vuonna 2018 esitti vakavissaan, kuinka Suomen NATO-jäsenyydestä ei pitäisi järjestää kansanäänestystä. Syyksi Haavisto kertoi sen, että demokraattista päätöksentekoa saatetaan sotkea ulkomaisten vaikuttajien taholta. Haavisto pelkäsi, että ihmiset saattaisivat äänestää "väärin", koska eivät osaa itse arvioida mikä on oikeaa ja väärää tietoa, mikä hyvää ja mikä huonoa. Tämän ajatuksen mukaan demokratiaan ja maailmanpolitiikkaan aina kuulunut painostus ja propaganda on nyt johtanut tilanteeseen, jossa kansaa ei voi päästää tekemään vääriä päätöksiä. Donald Trumpin valinnan ja Britannian Brexit-äänestyksen ajatellaan osoittavan, kuinka "äänestysvirheillä" voi olla kohtalokkaita vaikutuksia.

Kun Timo Soinin johtamat perussuomalaiset voittivat vaaleissa 2011 ja 2015, moni päättäjä, tutkija tai itseään muuten parempana pitävä henkilö totesi, että kansa oli äänestänyt täysin järjettömästi ja väärin. Kehä kolmosen takainen maailma nimettiin persujen asuttamaksi junttilaksi, kun taas esimerkiksi Helsingin Kallion kerrottiin vastapuolen sanoin muodostavan punaviherkuplan. Eliittiä nähtiin siis siellä missä sitä ei oikeastaan ole, ja juntteja ja jopa fasisteja siellä missä asuu tavallisia, fiksuja ja työnsä tekeviä ihmisiä.

Demokratian jakaantumisen "tietävään" eliittiin ja "tyhmään" kansaan, tai "tyhmään eliittiin" ja "tietävään kansaan" voisi sanoa olevan yksi demokratian ikiaikaisista kysymyksistä. Siitä kirjoittivat jo antiikin Kreikan filosofit kuten Platon ja Aristoteles, ja siitä oli huolissaan antiikin Ateenan kuuluisa lakiensäätäjä Solon. Thukydideen Peloponnesolaissota kertoo seikkaperäisesti kuinka Ateenan valistuneen strategos Perikleen johtama Ateena ajautuu sodan myötä kaaokseen ja menettää otteensa demokratiasta erilaisten kansankiihottajien ja populistien puristuksessa. ${ }^{1}$ Platonin nimissä kulkevien dialogien kuvaama Sokrateen ihastus Alkibiades oli yksi häikäilemättömimmistä demokratian väärinkäyttäjistä ${ }^{2}$, ja kuten Plutarkhoksen kirjoittama epäilemättä liioitteleva Alkibiadeen elämäkerta osoittaa, hänellä ei ollut "omaatuntoa" joka olisi estänyt toimimasta milloin demokraattisen Ateenan, milloin totalitaristisen Spartan johdossa. ${ }^{3}$

Demokratia ei siis ole kriisissä ensimmäistä kertaa. Päinvastoin, demokratia on ollut kriisissä ja voimakkaassa vastatuulessa heti syntymästään lähtien antiikin Ateenan klassiselta aikakaudelta. Länsimaiden historian ei voi sanoa olevan kokonaisuudessaan demokratian historiaa, sillä demokratiat tai keskustelut siitä eivät ole suinkaan olleet vuosissa mitattuna vallitseva hallitusmuoto. Mutta jos länsimailla on jotain erityistä poliittista perinnettä, liittyy se varmastikin demokratiaan ja erityisesti demokratiaa koskevaan poliittiseen filosofiaan.

Nykypäivän demokratian kriisissä eläville kansalaisille demokraattisen ajattelun historia ei ole välttämättä tuttu. Demokratiasta 
liikkuu monenlaista tietoa ja monenlaista tulkintaa. Kai Alhasen ja Tuukka Perhoniemen erinomainen, helppolukuinen ja inspiroiva Demokraattinen perintömme auttaa ymmärtämään, että juuri tämä on itseasiassa demokratian keskeisin piirre. Demokratian on oltava monipuolista, monitulkintaista ja jopa sekavaa ollakseen demokratiaa. Meidän velvollisuutemme on puolestaan tuntea ja ymmärtää demokraattisen ajattelun perinnettä, mihin teos antaa erinomaiset lähtökohdat.

\section{TEEMOJEN KAUTTA DEMOKRATIAAN}

Demokraattinen perintömme on jaettu neljään päälukuun, jotka kuvaavat demokraattisen ajattelun aikakausia. Liikkeelle lähdetään antiikin Kreikasta ja Roomasta, josta hypätään yli 1500 vuotta uuden ajan alkuun. Kolmas osa koskee modernin demokratian perustuksia ja neljäs nykyaikaa. Kirja käsittelee vain länsimaista demokraattista ajattelua. Muiden kielija kulttuurialueiden demokraattisen ajattelun perinteet rajautuvat ulos, vaikka esimerkiksi Kiinasta voisi olla löydettävissä erilaisia filosofisia koulukuntia ja hallintokäytäntöjä, jotka tulevat ainakin lähelle demokratian periaatteita. Kiinassa tietyt kungfutselaisuuden kriittiset haarat voidaan nähdä demokraattisina, samoin kuin mohistien koulukunnan ja Mozin (n. 470-391 eaa.) ajatukset. ${ }^{4}$

Aikakausista keskiaikaa ei ole mukana, mikä sekin on ymmärrettävä rajaus. Etenkin varhaiskeskiajalla antiikin Kreikan ja Rooman perintö hävisi eikä eurooppalaista politiikkaa tuolta ajalta tunneta kovinkaan demokraattisena. Demokratian ajattelu alkoi kuitenkin vahvistua jo 1100-luvulla. Kirjaan olisi voinut ottaa mukaan esimerkiksi Johannes Salisburylaisen (1120-1180) olennaisen tärkeät pohdinnat body politic -metaforasta Policraticusteoksessa, joka on eräällä tapaa ensimmäinen varsinainen politiikan filosofiaa käsittelevä teos keskiajalla. ${ }^{5}$ Modernin sekulaarin poliittisen järjestelmän kannalta olennaisen tärkeitä teoksia ovat myös esimerkiksi Danten (12651321) De Monarchia ja etenkin Marsilius $\mathrm{Pa}-$ dovalaisen (1275-1342) Defensor Pacis. ${ }^{6}$ Näissä molemmissa teoksissa hengellinen ja maallinen valta erotellaan selvästi, ja padovalaisen tapauksessa suvereenin vallan nähdään jopa perustuvan kansan, ei jumalan antamaan auktoriteettiin. Myös monet muut ruhtinaanpeilitradition tekstit ja kirjat myöhäiskeskiajalta tai oikeastaan varhaisrenessanssista olisivat voineet tulla hyvinkin lasketuiksi demokratian historiaan. Nyt uusi aika alkaa, perustellusti, Machiavellista, mutta Machiavellia edeltänyt runsas ruhtinaanpeilitraditio jää näkymättömiin.

Kirjan neljä teemaa sisältää kukin 6-9 käsitettä, kuten keskustelutaito, tasavalta, toimintamahdollisuudet, vapaa talouselämä, vallankumous, oikeusvaltio, maailmanrauha, ybdistymisvapaus ja totalitarismi. Demokratiaa ei siis ensisijaisesti lähestytä kirjoittajien ja teoreetikkojen, vaan teemojen kautta. Käytännössä jokainen teema keskittyy kuitenkin yhden keskeisen demokraattiseen ajatteluun vaikuttaneen teoreetikon esittelyyn. Teemoja lähestytään kontekstoivalla ja teemaa aukaisevalla pohdinnalla sekä teoreetikkojen keskeisten tekstikappaleiden laajoilla sitaateilla. Kirjoittajat ovat valinneet käytetyt tekstit hyvällä maulla ja perustellusti. Etenkin klassikoiden kohdalla on helppoa löytää hassuja tai negatiivisia sitaatteja, mutta Demokraattinen perintömme -kirjan kirjoittajat eivät ole hassuttelemassa tai mustamaalaamassa. Kirja esittelee kriittisesti, mutta asiallisesti ja arvostaen myös sellaisia kirjoittajia kuten Platon, joita ei varsinaisesti voida pitää demokratian puolustajina. Tekstikatkelmien ja niitä kontekstoivien ja selittävien analyysien kautta lukijalle syntyy nopeasti hyvä kuva esitellystä teemasta sekä aikakauden ajattelutavoista.

Kirjoittajien valinta rakentaa teoksen "juoni" teemojen ja käsitteiden kautta on toimiva siinäkin mielessä, että kyse on nimenomaan perinnöstä. Perintö on aina elävää ja toimivaa, mutta myös avointa uudelleentulkinnoille ja 
-luennoille. Perintö ei ole dogma tai sääntökokoelma. Temaattisen lähestymistavan kautta kirjoittajat pystyvät osoittamaan, kuinka monet satoja tai tuhansia vuosia sitten käsitellyt ongelmat ja kysymykset ovat edelleen tärkeitä ja ajankohtaisia. Kirja herättää demokratian historian eloon ja tuo syvyyttä jokapäiväisiin median jakamiin ja käsittelemiin poliittisiin kysymyksiin. Se avaa lukijalle siis demokratian kerrokset tai sedimentit. Se auttaa meitä ymmärtämään menneisyyttä ja pohtimaan, mistä esimerkiksi Ranskan tai Yhdysvaltain vallankumouksessa todella oli kysymys. Samalla se auttaa tekemään aikalaisanalyysia ja ymmärtämään missä kuljemme nyt.

\section{DEMOKRATIA SAA MEIDÄT AJATTELEMAAN}

Kirja on monin tavoin pedagoginen, mutta ei holhoava tai ohjaava. Klassikkoja ja poliittista filosofiaa paremmin tuntevan se laittaa ajattelemaan asioita uudelleen palauttaen mieleen keskeisten filosofien hienouden. Poliittista ajattelua tuntemattomille kirja on taas erinomainen johdatus ja lukuopas jatkotutustumista varten. Kirjaa voikin suositella niin nuorille kuin vanhemmille poliittisen ajattelun aloittelijoille ja mielestäni se sopisi erinomaisesti lukiolaisten oppikirjaksi. Yliopistoissakin kirjaa voi hyvin käyttää politiikan teorian oheislukemistona ja johdatuksena.

Poliittisen ajattelun klassikot kestävät aikaa ja ne haastavat meitä yhä uudelleen uudenlaisissa konteksteissa. Kirjan lukija ei voi välttyä ajatukselta, että demokratiaan liittyvä monipuolinen keskustelu, kiistat, epäluottamus ja konfliktit ovat niitä tekijöitä jotka saavat meidät itse asiassa ajattelemaan: ajattelemaan uudelleen, monipuolisesti ja erilaisista näkökulmista. Tiedettä ja tutkimusta voidaan periaatteessa tehdä totalitaarisissa järjestelmissä. Mutta uskaltaisin väittää, että ajattelun vapaa kehittyminen on demokratialle tyypillisempää kuin totalitarismille tai vaikkapa aristokratialle. Totalitaristisessa järjestelmässä kriittinen ajattelu kiertyy yhden aiheen, totalitaristisen vallan tai sitä pakenevan mielikuvituksen ympärille. Toki demokratiassakin erilaiset tilanteet pakottavat meidät ajattelemaan tiettyjä, ajankohtaisia kysymyksiä, mutta demokratiassa kysymys- ja vastausmahdollisuudet eivät ole rajoitettuja, eikä niillä pyritä välttämättä välittömiin muutoksiin.

Demokratian tavoitteena voitaisiinkin pitää tilannetta, jossa kaikki voivat ajatella vapaasti ja esittää ajatuksensa kokematta pelkoa tai huolta siitä, että ajatusten esittämisellä on negatiivisia vaikutuksia heihin itseensä. Tämä ei tarkoita sitä, että yksikään demokratia voisi olla läpeensä turvallinen, tasapuolinen tai tasavertainen järjestelmä. Demokratian ajattelu ja erityisesti sen käytäntöjen toteuttaminen ja puolustaminen vaatii rohkeutta, eikä se voi toteutua vain vaatimalla muilta asiallista käytöstä. Demokratia vaatii myös voimakkaita tekoja ja vastakkainasettelun kautta rakentuvia vaatimuksia. Demokraattisen ideaalin tasolla monipuolisten asiasisältöjen lisäksi demokraattinen keskustelu koskee aina myös demokraattisen keskustelun, hallinnan ja käytäntöjen ehtoja. Demokratian tehtävänä on pohtia asioita ennen toimintaa, mutta myös käsitellä toiminnan seurauksia.

Tämä kirja-arvio on sadas julkaistu kirjaarvioni. Suurin osa arvioimistani kirjoista on ollut filosofisia ja yhteiskuntatieteellisiä teoksia, pääasiassa suomennoksia. Haluan kiittää tässä erityisesti kaikkia suomentajia ja suomenkielisten kirjojen kirjoittajia ja toimittajia. Työnne on tärkeää ja olennainen osa tieteellistä elämää. Saman kiitoksen haluan esittää kaikille suomalaisille tiede- ja kulttuurilehdille, jotka julkaisevat edelleen kirja-arvioita ja pitävät niitä arvokkaina. Kaiken tieteellisen ja erityisesti yhteiskuntatieteellisen toiminnan ytimessä on keskusteleva yhteisö.

Usein tieteellinen keskustelu käydään nimenomaan pitkien, kirjoina julkaistujen tutkimusten ja puheenvuorojen muodossa. On tärkeää, että näitä tutkimuksia luetaan ja kommentoidaan niin lyhyissä kuin pitkissäkin 
kirja-arvioissa. Ne tarjoavat foorumin monenlaisille kehittelyille ja avaavat polkuja jatkokeskusteluille. Kirja-arviot ovat olennaisia myös siksi, että toistaiseksi tieteellisiä artikkeleita ei arvioida vertaisarviointiprosessin lisäksi millään muulla foorumilla. On huolestuttavaa, että kun yhä suurempi osa tieteestä julkaistaan nimenomaan artikkeleina, jää niiden kriittinen arviointi ja niistä syntyvä keskustelu puolitiehen. Toki tieteelliset keskustelut arvioivat jatkuvasti aiemmin esitettyjä tutkimuksia ja näkökulmia, mutta tästä huolimatta artikkeleiden arviointifoorumeita odotellessa kirjaarviot ovat tieteellisen keskustelun ainoa elävä ja suuremmalle yleisölle näkyvä foorumi.

Itselleni sadan kirja-arvion kirjoittaminen viimeisen 14 vuoden aikana on ollut ennen kaikkea oppimismatka. Joskus kymmenien

\section{VIITTEET}

1. Thukydides: Peloponnesolaissota. WSOY. Helsinki 1964.

2. Platon: Alkibiades I ja Alkibiades II. Teoksessa Teokset VII. Otava. Helsinki, 1999.

3. Plutarkhos: Kuuluisien miesten elämäkertoja. WSOY. Helsinki 2005.

4. Katso tarkemmin Jyrki Kallio (toim.): Mestari Kongin sivujen mittaisiksi venyneet tekstit ovat akateemisten meriittien kannalta turhia, elleivät jopa haitallisia. Joidenkin talousrationaalisesti orientoituneiden ja palkitsemismittareita palvovien tieteilijöiden mukaan olen varmastikin heittänyt aikaani hukkaan. Oma kokemukseni on kuitenkin kaikkea muuta. Olen saanut lukea ja syventyä lukemaani kirjoittamalla rajatusti yhdestä aiheesta. Ehkä jotkut ovat myös lukeneet arvioitani. Toivon, että tiedeyhteisö muistaisi myös tulevaisuudessa kirja-arvioiden merkityksen niin tutkimukselle kuin tiedeyhteisön kehittymiselle. Kirja-arviot ja tieteellinen keskustelu kun on yksi demokraattisen järjestelmän esimerkillisimpiä piirteitä. Se on perintö, josta meillä ei ole varaa luopua.

— MIKKO JAKONEN opetukset. Gaudeamus. Helsinki 2015 ja Mee-tse: Kaksitoista kirjaa. WSOY. Helsinki, 1964.

5. John of Salisbury: Policraticus. Cambridge University Press. Cambridge 1990.

6. Dante: Monarchy. Cambridge University Press. Cambridge 1996; Marsilius of Padua: The Defender of the Peace. Cambridge University Press. Cambridge 2006.

\section{NUMEROMME KIRJOITTAJAT}

SAMULI HURRI OTT, yliopistonlehtori, oikeustieteiden tiedekunta, Lapin yliopisto. RIIKKA THERESA INNANEN Kuvataiteilija, aktivisti, koreografi.

MIKKO JAKONEN YTT, dos., kulttuuripolitiikan yliopistonlehtori (ma.), Jyväskylän yliopisto.

ILKKA LINDSTEDT FT, dos., yliopistotutkija, Helsingin yliopiston tutkijakollegium.

JANI LUKKARINEN YTM, Suomen ympäristökeskus, Politiikkakeskus

NIINA NIKKI TT, tutkijatohtori, teologinen tiedekunta, Helsingin yliopisto.

TEIJO RYTTERI FT, Historia- ja maantieteiden laitos, Itä-Suomen Yliopisto.

JOHANNA SUMIALA FT, dos. apulaisprofessori, uskontotiede, Helsingin yliopisto.

REIMA VÄLIMÄKI FT, tutkijatohtori, kulttuurihistoria, Turun yliopisto. 